\title{
Pemurnian Bioetanol dengan Distilasi Rektifikasi Tipe 'Sieve Tray' untuk Menghasilkan FGE (Fuel Grade Etanol)
}

\section{Purification of Bioethanol with a Sieve Tray Type Rectification Distillation to Produce FGE (Fuel Grade Ethanol)}

\author{
Yuana Susmiati ${ }^{\# 1}$, Mochamad Nuruddin ${ }^{\# 2}$, Agus Nursalim \\ ${ }^{\#}$ Jurusan Teknik, Politeknik Negeri Jember \\ Jl. Mastrip Kotak Pos 164 Jember \\ ${ }^{1}$ yuanasusmiati@gmail.com \\ ${ }^{2}$ mohnuruddin2@gmail.com
}

\begin{abstract}
Bioethanol can be used as a substitution of fosil fuel as a fuel stove or motor vehicle. In the ordinary distillation bioethanol production process is only able to produce 50-70\% of ethanol which can only be used to fuel stove. To obtain high-grade bioethanol, a multilevel distillation process is required. One of the distillation methods to purify bioethanol is rectification distillation. The purpose of this research is to design a sieve tray type rectifier distillation apparatus that used to increase the bioethanol content. The results showed that the device can increase the ethanol content from $37 \%$ to $90 \%$.
\end{abstract}

Keywords — bioethanol, rectification distillation, purification.

\section{Pendahuluan}

Bioetanol sebagai bahan bakar alternatif pengganti BBM diolah dari bahan nabati yang potensial mengandung glukosa melalui proses sakarifikasi, fermentasi dan pemurnian produk. Fermentasi bioetanol biasanya menghasilkan etanol berkadar rendah seperti yang telah dilakukan oleh Susmiati [1] yaitu fermentasi bioetanol oleh Saccharomyces cerevisiae pada ubi kayu yang dihidrolisis secara asam menghasilkan 7,18 \% (v/v) dan ubi kayu yang dihidrolisis secara enzimatis sebesar 9,59\% (v/v). Secara teoritis fermentasi etanol oleh Saccharomyces cerevisiae menghasilkan etanol 12-18\% (v/v) seperti yang disampaikan oleh Gaur [2]. Oleh karena itu perlu adanya tahap proses pemurnian etanol yang pada umumnya menggunakan proses destilasi.
Pada proses destilasi etanol, larutan fermentasi yang terdiri dari campuran etanol, air dan bahanbahan lainnya dipisahkan pada tekanan amosfir dengan suhu tertentu. Pada suhu $100^{\circ} \mathrm{C}$ air mendidih dan akan menguap, sedangkan etanol mendidih pada suhu sekitar $78{ }^{\circ} \mathrm{C}$. Perbedaan titik didih inilah yang memungkinkan pemisahan campuran etanol dan air. Dengan destilasi biasa/sederhana pemurnian etanol dari fermentasi tape ubi kayu dapat diperoleh kadar etanol destilat sebesar 58,58\% v/v yang diperoleh pada suhu proses $71^{\circ} \mathrm{C}$, selama 5 jam [3]. Selain itu Summers [4] juga menyatakan bahwa pemurnian hasil fermentasi yang dilakukan dengan distilasi sederhana dimana alatnya terdiri dari boiler dan kondensor satu tahap akan menghasilkan etanol $40 \%$ volume, sedangkan jika distilasi dilakukan dua kali kadar etanolnya meningkat menjadi $70 \%$ volume.

Aplikasi bioetanol sebagai bahan bakar dapat dilakukan pada etanol berkadar 50-70\% untuk 

kompor, sedangkan untuk kendaraan bermotor dibutuhkan etanol berkadar tinggi yaitu $99 \%$ yang disebut dengan Fuel Grade Etanol sebagaimana disampaikan oleh Nurdiyastuti [5] dan Prihandana [6]. Masalah yang timbul adalah sulitnya memisahkan hydrogen yang terikat dalam struktur kimia alkohol dengan cara destilasi biasa. Oleh karena itu untuk mendapatkan FGE dilaksanakan pemurnian lebih lanjut dengan cara Azeotropic

Metode destilasi yang mungkin diaplikasikan dalam proses pemurnian bioetanol untuk mendapatkan etanol yang berkadar tinggi adalah destilasi dengan refluks atau rektifikasi. Destilasi rektifikasi dilakukan dengan mendidihkan cairan menjadi uap yang kemudian diembunkan dan sebagian uap yang mengembun ini dikembalikan ke dalam kolom distilasi untuk dikontakkan dengan uap. Aliran kontak antara uap dan cairan dilakukan melalui beberapa stage atau tray, cairan akan turun ke bawah sedangkan uap akan naik keatas. Selama terjadinya kontak antara uap dan cairan akan terjadi kesetimbangan atau menuju kesetimbangan uap-cair [7].

Pada penelitian ini akan dilakukan rancang bangun alat distilasi rektifikasi tipe sieve tray. Penelitian ini dilakukan untuk menyempurnakan penelitian sebelumnya yaitu rancangan alat-alat produksi bioetanol skala rumah tangga yang salah satunya adalah alat destilasi. Pada penelitian terdahulu bioetanol yang mampu dihasilkan adalah bioetanol dengan kadar rendah yaitu $50-70 \%$ [8], sehingga dengan penelitian ini diharapkan dapat diperoleh bietanol berkadar tinggi yaitu lebih dari 95\% bahkan termasuk Fuel Grade Bioetanol (FGE).

\section{METODE PENELITIAN}

\section{Alat dan Bahan Penelitian}

Alat yang digunakan dalam penelitian ini meliputi alat alat gelas dalam laboratorium (seperti gelas ukur, beker gelas dan lainnya), piknometer, alkohol meter, handrefraktometer, timbangan digital, alat produksi bioetanol skala laboratorium dan alatalat perbengkelan dan kelistrikan.

Bahan yang digunakan adalah bahan bahan proses pembuatan bioetanol dan bahan pembuatan alat distilasi. Bahan pembuatan bioetanol meliputi molasses, ragi roti, urea dan $\mathrm{NPK}, \mathrm{H}_{2} \mathrm{SO}_{4}$, serta air. Selain itu juga diperlukan etanol teknis yang digunakan untuk uji coba. Sedangkan bahan pembuatan alat distilasi meliputi plat dan pipa stainless stell dalam berbagai ukuran, heater/pemanas, dan komponen-komponen elektronika.

\section{Tahapan Penelitian}

Penelitian dilakukan dengan berbagai tahap yaitu : destilasi. Azeotrop adalah keadaan dimana suatu larutan mempunyai fasa uap dan fasa cair yang sama saat dididihkan [5]. Etanol dan air mempunyai perbedaan titik didih yang cukup signifikan tetapi pada konsentrasi tertentu keduanya mempunyai titik didih yang sama yang disebut dengan sifat azeotrop. Pada tekanan 1 atm dan konsentrasi etanol 95\%, air akan sulit dipisahkan dari etanol [4].

1. Tahap pembuatan bahan uji coba berupa bioetanol dengan kadar 50-60\%.

2. Tahap perancangan dan pembuatan alat distilasi rektifikasi.

3. Tahap pengujian alat distilasi rektifikasi.

4. Tahap perbaikan dan modifikasi alat distilasi rektifikasi.

Pada tahap penyiapan bahan uji coba alat, dilakukan pembuatan bioetanol dari molasses yang berkadar gula tinggi $60 \%$, diencerkan, disterilisasi, diatur $\mathrm{pH}$-nya, ditambahkan nutrisi berupa urea dan NPK serta penambahan ragi roti untuk proses fermentasi. Setelah difermentasi selama 3 hari kemudian didistilasi dan menghasilkan bioetanol dengan kadar 50-60\%. Proses dilakukan dengan menggunakan alat proses pembuatan bioetanol skala rumah tangga yang sudah ada di Laboratorium Teknik Energi Terbarukan.

Alat distilasi rektifikasi dirancang sedemikian dengan tujuan alat tersebut dapat memurnikan bioetanol yang dihasilkan hingga 90-95\%. Alat distilasi yang dirancang terdiri dari komponen utama steam boiler, kolom bawah, kolom distilasi (atas) yang di dalamnya terdapat piringan yang tersusun dan kondensor. Alat direncanakan bekerja dalam kapasitas 1-3 liter etanol. Setelah gambar rancangan siap, maka dilanjutkan dengan proses pembuatan alat distilasi rektifikasi di bengkel las.

Tahap pengujian alat dilakukan untuk menguji apakah alat yang dirancang dan dibuat telah bisa berfungsi dengan baik, dan bagaimana kinerjanya yang ditunjukkan dengan kemampuan alat untuk meningkatkan kadar etanol bahan uji coba.

Setelah proses pengujian alat secara fungsional dan kinerja dilakukan, maka perlu adanya perbaikan dan modifikasi alat tersebut. Tujuan dari tahapan ini adalah untuk meningkatkan kinerja dari alat itu sendiri yaitu semakin efektif dan efisien dalam proses pemurnian bioetanol.

\section{III.HASIL DAN PEMBAHASAN}

\section{Pembuatan Bioetanol Bahan Uji Alat dari Molases}

Molases sebanyak $6400 \mathrm{ml}$ diencerkan dengan menambah air sebanyak $23600 \mathrm{ml}$ sehingga diperoleh nilai brix sebesar $23 \%$ dan nilai $\mathrm{pH} \mathrm{5,}$ kemudian media dipasteurisasi yang bertujuan untuk mematikan patogen atau bakteri yang dapat 
Yuana Susmiati, Mochamad Nuruddin. Pemurnian Bioetanol dengan Distilasi Rektifikasi Tipe 'Sieve

Tray' untuk Menghasilkan FGE

mengganggu proses fermentasi. Pasteurisasi dilakukan pada suhu $85{ }^{\circ} \mathrm{C}$ selama 10 menit. Setelah pasteurisasi selesai, media didiamkan hingga mencapai suhu ruangan yaitu $30-35{ }^{\circ} \mathrm{C}$.

Komposisi mikroba dan nutrisi yang ditambahkan pada proses fermentasi adalah sebagai berikut :

Ragi $\quad: 0,5 \%$ x \%brix $x$ volume media $=34,5 \mathrm{gr}$

NPK : $0,06 \% \times \%$ brix $x$ volume media $=4,14 \mathrm{gr}$

Urea $: 0,5 \% \times \%$ brix $x$ volume media $=34,5 \mathrm{gr}$

ZA $: 0,1 \% \times \%$ brix $x$ volume media $=6,9$ gr.

Sebelum ditambahkan ke media fermentasi (molases yang sudah dipasteurisasi), terlebih dahulu ragi dibiakkan dalam air hangat dengan suhu $40^{\circ} \mathrm{C}$ sebanyak $10 \%$ volume total media. Begitu juga dengan NPK, Urea dan ZA masing-masing dilarutkan ke dalam air sebanyak $500 \mathrm{ml}$. Fermentasi dilakukan setelah media yang di pasteurisasi bersuhu kurang dari 35 oC, selama 48 jam. Setelah itu dilakukan proses destilasi dan dihasilkan bioetanol sebanyak $1395 \mathrm{ml}$ dengan kadar 69\%. Destilasi yang dilakukan kurang efektif karena lajunya sangat kecil yaitu rata-rata $116,25 \mathrm{ml}$ perhari. Hal tersebut dikarenakan adanya kebocoran uap pada alat destilasi yang digunakan sehingga banyak etanol yang menguap sebelum sampai ke penampungan. Pembuatan bioetanol diulangi lagi dan menghasilkan sebanyak $1144 \mathrm{ml}$ sehingga total etanol yang dihasilkan sebanyak $2539 \mathrm{ml}$.

\section{Perancangan dan Pembuatan Alat Distilasi Rektifikasi}

Alat destilasi rektifikasi yang dibuat membutuhkan daya listrik sebesar 2060 watt, yang terdiri atas daya pada elemen pemanas steam (boiler) sebesar 2000 watt, dan daya pada pompa kondensor sebesar 60 watt.

Kapasitas alat tersebut adalah 3 liter bahan masukan dan terdiri dari komponen penting yaitu reboiler, kolom bawah, kolom tray, kondensor, pipa pendingin dan tangki penampung distilat.

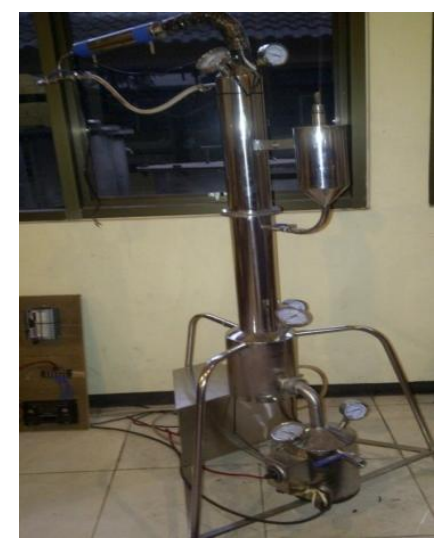

GAMBAR 1. ALAT DISTILASI REKTIFIKASI YANG TELAH DIBUAT
- Reboiler/steam boiler berfungsi untuk memanaskan air hingga menghasilkan uap panas yang selanjutnya dialirkan ke dalam kolom bawah. Sumber panas dari reboiler adalah elemen listrik yang diletakkan di bawah tangki reboiler.

- Kolom bawah berfungsi untuk memanaskan bioetanol yang akan didistilasi.

- Kolom tray berfungsi sebagai pemurni etanol dengan system tray bertingkat-tingkat. Kolom tray terbuat dari pipa stainless steel yang berdiameter luar $7,62 \mathrm{~cm}$, tebal $0,2 \mathrm{~cm}$ serta panjang $100 \mathrm{~cm}$. Di dalam kolom tray ini dipasang piringan-piringan yang dibuat dari plat stainless steel yang teriris bagian tepinya sebagai jalannya bahan.

- Kondensor berfungsi sebagai penukar kalor yaitu menyerap kalor dari uap etanol ke air yang melewati kondensor sehingga terjadi proses kondensasi.

- Tangki penampung distilat berfungsi untuk menampung bioetanol setelah proses destilasi. Pada tangki ini dibagi menjadi dua saluran yaitu saluran refluks dan saluran hasil atas (top product). Pembagi aliran etanol dalam penampung distilat menggunakan katup.

\section{Pengujian Alat Distilasi Rektifikasi}

Pada proses pengujian alat distilasi berlangsung selama 100 menit dengan kebutuhan energi listrik sebesar 600 wh. Pada awal proses boiler diisi air sebanyak $3000 \mathrm{ml}$ dan ketika proses berakhir berkurang menjadi $2720 \mathrm{ml}$, sedangkan pada bak pendingin ketika awal diisi dengan air sebanyak $11000 \mathrm{ml}$ berubah menjadi $11200 \mathrm{ml}$. Cairan distilat menetes pertamakali pada menit ke 27 . Perubahan kadar etanol bahan distilasi ditunjukkan pada Tabel 1 berikut ini.

TABEL 1. KADAR ETANOL SEBELUM DAN SESUDAH PROSES DISTILASI

\begin{tabular}{|c|c|c|c|}
\hline \multirow[b]{2}{*}{$\begin{array}{l}\text { Keberadaan } \\
\text { etanol }\end{array}$} & \multirow[b]{2}{*}{$\begin{array}{l}\text { Volume } \\
\text { (ml) }\end{array}$} & \multicolumn{2}{|c|}{ Kadar etanol (\%) } \\
\hline & & $\begin{array}{c}\text { alk.mete } \\
\mathrm{r}\end{array}$ & $\begin{array}{c}\text { picn } \\
\text { o }\end{array}$ \\
\hline & & & 37,6 \\
\hline \multirow[t]{2}{*}{ Masukan } & 916 & 38 & 6 \\
\hline & & & 52,9 \\
\hline \multirow[t]{2}{*}{ Distilat } & 26 & & 5 \\
\hline & & & 22,9 \\
\hline Bottom & 932 & 22 & 2 \\
\hline
\end{tabular}

Sebaran suhu pada proses distilasi juga diamati pada steam, bottom, menara dan kondensor dan ditunjukkan oleh grafik pada Gambar 2 seperti berikut ini. 


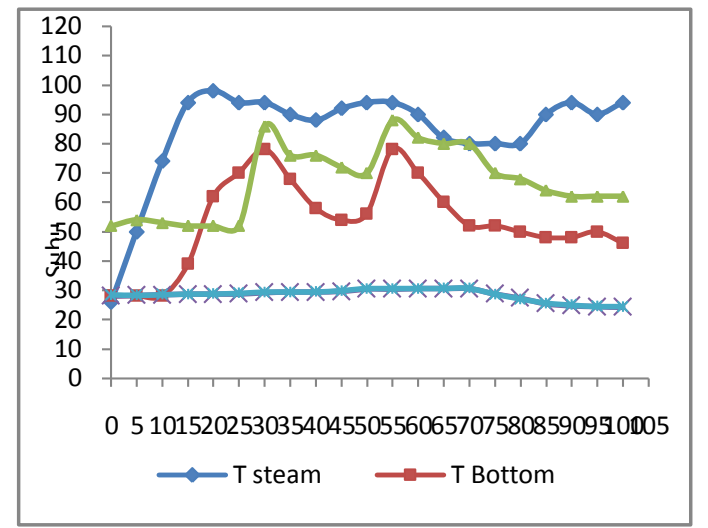

GAMBAR 2. GRAFIK SEBARAN SUHU PADA PROSES DIETILASI

Proses distilasi diawali dengan pengisian air pada steam/boiler sebanyak $3000 \mathrm{ml}$, serta pengisian air pada bak kondensor sebanyak $11000 \mathrm{ml}$, kemudian menghubungkan arus listrik alat dan mengeset suhu boiler pada angka $100^{\circ} \mathrm{C}$. Pengaturan suhu tersebut bertujuan untuk mendidihkan air pada boiler sehingga uap panas dapat memasuki ruang kolom bawah (bottom). Etanol dengan kadar rendah (37-38\%) dimasukkan ke tabung pemasukkan bahan tetapi kran masih tertutup. Setelah suhu bottom mencapai sekitar 80oC kran pada masukkan dibuka.

Sesuai dengan Tabel 1 tentang kondisi etanol pada proses distilasi dapat diketahui bahwa pengukuran kadar etanol dengan metode picnometer dan pemakaian alkoholmeter tidak jauh berbeda, sehingga jika distilat yang didapatkan banyaknya tidak memenuhi untuk pengukuran dengan alkoholmeter, metode picnometer dapat digunakan atau dapat mewakili data yang dibutuhkan.

Pada proses distilasi rektifikasi dapat meningkatkan kadar etanol bahan yaitu dari $38 \%$ menjadi $53 \%$ dengan volume distilat sebanyak $26 \mathrm{ml}$ dan volume bottom $932 \mathrm{ml}$. Total volume distilat dan bottom pada proses ini sebanyak $958 \mathrm{ml}$ sehingga terjadi kenaikan sebesar $42 \mathrm{ml}$ dari volume masukan. Hasil etanol pada proses tersebut sangat dipengaruhi oleh sebaran suhu alat distilasi.

Sebaran suhu distilasi menunjukkan suhu menara adalah suhu paling tinggi dibandingkan suhu pada bottom dan menara. Suhu air kondensor juga mempunyai kecenderungan yang sama yaitu semakin lama semakin naik. Selisih suhu air masuk dan air keluar pada kondensor tidak terpaut jauh yaitu hanya sekitar 0,1-0,3 bahkan pada waktu tertentu tidak berbeda antara suhu air masuk dan air keluar kondensor. Hal tersebut menunjukkan bahwa proses penukar atau pemindahan panas yang terjadi sudah mencukupi untuk proses distilasi tersebut.
Berdasarkan Gambar 2 dapat diketahui bahwa terjadi fluktuasi suhu yang cukup tajam pada steam, bottom dan menara. Fluktuasi ini disebabkan oleh pengaturan suhu elemen pemanas steam secara manual, dimana kontrol suhu mempunyai range/selisih yang cukup jauh. Oleh karena itu perlu penggantian kontrol suhu pada pemanas steam yang anual menjadi digital agar dapat diatur selisih suhunya tidak terlalu jauh sehingga suhu dapat bertahan pada titik tertentu.

\section{Modifikasi Alat Distilasi Rektifikasi}

Setelah proses pengujian diputuskan perlunya modifikasi alat distilasi yang telah dibuat. Modifikasi yang dilakukan bertujuan untuk meningkatkan kinerja alat. Dari hasil analisa, alat tersebut perlu adanya pemanas dibagian bottom yang bekerja semacam penukar kalor dan perlu adanya kontrol suhu untuk menghindari fluktuasi suhu yang terlalu tajam. Penukar kalor tersebut bekerja sebagai koil pemanas, yang memanaskan bioetanol sehingga terjadi proses penguapan etanolnya. Penukar kalor dibuat dari lima tabung tertutup yang disusun berdiri sejajar, dan diharapkan dengan adanya penukar kalor ini proses pemanasan bioetanol yang akan dimurnikan lebih efektif, serta tidak terjadi percampuran antara uap panas dari steam boiler dan bahan, sehingga hasil yang didapatkan lebih baik.

Kontrol suhu dipasang pada elemen pemanas dibagian steam boiler, yang bertujuan untuk mengatur kestabilan suhu yang ada di bagian bottom dan menara distilasi. Dengan adanya suhu yang relatif stabil, diharapkan proses pemurnian juga lebih baik.

Setelah dimodifikasi alat distilasi diuji kembali dan hasil pengujian seperti ditunjukkan pada table berikut ini.

TABEL 2. HASIL UJI ALAT DISTILASI TERMODIFIKASI

\begin{tabular}{lll}
\hline Bahan & Volume & $\begin{array}{l}\text { Kadar } \\
\text { etanol }\end{array}$ \\
\hline Masukkan & $1000 \mathrm{ml}$ & $37 \%$ \\
Distilat & $245 \mathrm{ml}$ & $90 \%$ \\
Bottom & $540 \mathrm{ml}$ & $10 \%$ \\
\hline
\end{tabular}

Proses pengujian alat distilasi setelah dimodifikasi berlangsung selama 145 menit. Berdasarkan hasil seperti yang ditunjukkan pada Tabel 2, ada peningkatan kinerja alat distilasi setelah dimodifikasi, yaitu bias menaikkan kadar etanol dari $37 \%$ menjadi 90\%. Dari hasil tersebut juga diketahui masih adanya loses pada proses.

\section{IV.KESIMPULAN}

Berdasarkan hasil penelitian yang telah dilakukan dapat disimpulkan bahwa alat distilasi rektifikasi tipe 
Yuana Susmiati, Mochamad Nuruddin. Pemurnian Bioetanol dengan Distilasi Rektifikasi Tipe 'Sieve Tray' untuk Menghasilkan FGE

sieve tray yang dibuat telah bekerja cukup baik meskipun belum sempurna yaitu mampu meningkatkan kadar etanol dari $37 \%$ menjadi $90 \%$.

\section{UCAPAN TERIMA KASIH}

Terima kasih disampaikan kepada KemenristekDikti melalui LPPM Polije yang telah mendanai penelitian ini dalam skim Hibah Bersaing.

\section{DAFTAR PUSTAKA}

[1] Susmiati. Y.Rekayasa Proses Hidrolisis Pati dan Serat Ubi Kayu untuk Produksi Bioetanol. Tesis. Fateta. IPB. 2010.

[2] Gaur. K. Process optimization for the production of ethanol via fermentation. Dissertation. Departement of Biotechnology and Environment Sciences Thapar Institute of Engineering \& Technology (Deemed University). Patiala-147004. Patiala Punjab India. 2006.

[3] Ardi. W.R. Pemurnian Etanol dari Fermentasi Tape Ubi kayu (Manihot utilissima), Kajian Suhu dan Lama Waktu Destilasi. Skripsi. Fateta Universitas Brawijaya. 2009.

[4] Summers. D.R. Rectifier Design for Fuel Ethanol Plants. Presented at the AIChE Annual Meeting Advances in Distillation Equipment and Applications Paper 264b. November 14, 2006. San Francisco. Sulzer Chemtech USA, Inc. . 2006.

[5] Nurddyastuti, I. Teknologi Proses Produksi Bioethanol. Makalah BBPT.http://www.reocities.com/markal_bppt/publis h/biofbbm/biindy.pdf. 2008.

[6] Prihandana, R., K. Noerwijari, P.G.Adinurani, D.Setyaningsih, S setiadi dan R.Hendroko. Bioetanol Ubi Kayu : Bahan Bakar Masa Depan. Agromedia Pustaka. Jakarta.. 2007.

[7] Abassato. Distilasi Sistem Tiga Komponen AsetonEtanol-Air dalam Kolom Sieve Tray. Prosiding Seminar Nasional Transfer Teknologi. ITATS. 15 November 2007.

[8] Susmiati. Y dan M. Nuruddin. Rancang Bangun Alat Produksi Bioetanol dari Onggok Ubi Kayu Skala Rumah Tangga. Laporan Penelitian belum terpublikasi. Polije. 2014. 